\title{
Evaluation of RU28318 and RU40555 as Selective Mineralocorticoid Receptor and Glucocorticoid Receptor Antagonists, Respectively: Receptor Measures and Functional Studies
}

\author{
Paul J. Kim, Michael A. Cole, Brian A. Kalman and \\ Robert L. Spencer ${ }^{\star}$ \\ Department of Psychology, University of Colorado, Campus Box 345, Boulder, CO 80309, U.S.A.
}

\begin{abstract}
Corticosterone regulates a wide range of physiological parameters. Two receptors for corticosterone have been identified, the mineralocorticoid (type I) receptor (MR) and the glucocorticoid (type II) receptor (GR). To determine the relative role of these two receptors in mediating the effects of endogenous corticosterone, many studies have relied on the use of putative selective corticosteroid receptor antagonists. This study further examined the in vivo receptor selectivity of two compounds, RU28318 and RU40555 that are believed to be selective antagonists for MR and GR, respectively. Acute treatment of adrenalectomized rats with RU28318 (10-50 mg/kg) selectively decreased ex-vivo available MR binding in the hippocampus, whereas acute treatment with RU40555 (10-30 mg/kg) selectively decreased available GR binding in the hippocampus and pituitary. These receptor binding measures suggest that RU28318 in vivo selectively occupied MR, and that RU40555 in vivo selectively occupied GR. In functional studies, RU28318 $(50 \mathrm{mg} / \mathrm{kg})$ blocked the normalizing effect of aldosterone $(120 \mu \mathrm{g} / \mathrm{kg})$ on saline intake of adrenalectomized rats. RU40555 (30 mg/kg) blocked the suppressive effect of dexamethasone $(50 \mu \mathrm{g} / \mathrm{kg})$ on acute stress-induced corticosterone secretion. These studies further support the in vivo corticosteroid receptor selectivity of these two compounds and confirms their effective corticosteroid antagonistic properties. (C) 1998 Elsevier Science Ltd. All rights reserved.
\end{abstract}

f. Steroid Biochem. Molec. Biol., Vol. 67, No. 3, pp. 213-222, 1998

\section{INTRODUCTION}

Corticosterone is a systemic hormone that has important regulatory effects on virtually every physiological system of the body. As the end-product of the hypothalamic-pituitary-adrenal (HPA) axis, corticosterone secretion is ultimately controlled by the brain. Activation of the HPA axis is primarily a result of circadian and stress reactive circuits in the brain converging on neurons in the paraventricular nucleus of the hypothalamus $[1,2]$. Thus, circulating corticosterone levels vary considerably throughout the day in response to changes in the environment, such as the

\footnotetext{
^Correspondence to R. L. Spencer. Tel. 492 0854; Fax: 492 2967; e-mail: spencer@clipr.colorado.edu. Received 30 Jan. 1998; accepted 9 Jun. 1998.
}

time of day and the presence or absence of stress. Cells throughout the body may optimize their function in the face of changing environmental demands by responding to fluctuations in corticosterone. The responsiveness of cells to corticosterone is dependent on expression of corticosteroid receptors. Two closely related receptors for corticosteroids have been identified, the mineralocorticoid receptor (MR or type I corticosteroid receptor) and the glucocorticoid receptor (GR or type II corticosteroid receptor) [3, 4]. These receptors differ in their affinity for corticosterone [5] and they can mediate different cellular effects [6]. Consequently, there may be separate roles of these two receptors in mediating the wide ranging effects of corticosterone on specific cell types and/or physiological systems. A very useful tool for 
determining these relative roles of $\mathrm{MR}$ and $\mathrm{GR}$ is in vivo treatment with selective receptor antagonists. Several different steroid analogues have been characterized which appear to be effective in selectively antagonizing corticosterone effects mediated by MR or GR. However, for each of these compounds the validation of their suitability for in vivo studies has been limited.

In recent years a number of studies have used RU28318 as a selective MR antagonist. RU28318 has been reported to be superior to the more traditional anti-mineralocorticoid, spironolactone, in terms of having a higher in vivo anti-mineralocorticoid activity and a lower anti-androgen activity [7]. However, in vitro receptor binding studies suggest that RU28318 may have considerable interaction with $\mathrm{GR}[8,9]$.

RU486 has been the most widely used compound for blocking GR, however, in many cases this compound has been found to have agonist properties [1014]. In addition, for the last several years the distribution of RU486 in the U.S.A. has been prohibited or severely restricted. A potential alternative selective GR antagonist is RU40555. This compound has been described by its developer (Roussel-Uclaf, Romainville, France) as having a similar receptor selectivity as RU486 (affinity for both glucocorticoid and progesterone receptors), but a lower potency for blocking glucocorticoid effects (unpublished correspondence with Roussel-Uclaf).

We report here studies that further evaluated the suitability of using RU28318 and RU40555 as selective $M R$ and GR antagonists for in vivo studies in the rat. Both the dose- and time-response effects of these drugs on available $M R$ and GR receptor binding were examined. From these studies we can estimate the proportion of MR and GR that are occupied in vivo by these compounds and thereby assess the extent to which these compounds selectively interact with MR and GR $[15,16]$. For the receptor binding studies we have utilized the hippocampus and pituitary. Hippocampal tissue was selected as a representative brain region. The hippocampus is an ideal tissue for available corticosteroid receptor measures because of its high expression of both $M R$ and GR. In addition, there is considerable interest among researchers in the relative roles of hippocampal $M R$ and GR expression in regulating a number of hippocampal formation related processes such as neuronal excitability [17], long-term potentiation [18], primed burst potentiation [19], neurotransmitter receptor expression [20-23], neuronal atrophy [24] and neuronal survival $[25,26]$. The pituitary was selected as a representative peripheral tissue that also has direct relevance for corticosteroid negative feedback actions on HPA axis activity.

In addition to available receptor binding studies, we have tested these compounds in functional stu- dies. These functional studies were designed to confirm in vivo the ability of these antagonists to block the effects of an agonist for MR or GR. Furthermore, these functional studies tested for possible agonist effects of these putative antagonist compounds. One of the best characterized physiological roles of MR is mediation of sodium retention by the kidney and a complementary regulation of sodium appetite [27]. Adrenalectomy of rats results in increased sodium intake, which can be normalized by treatment with the MR selective agonist, aldosterone [28, 29]. Therefore, we have tested the ability of RU28318 to functionally antagonize this $\mathrm{MR}$ mediated effect by examining saline intake in adrenalectomized rats treated with aldosterone \pm RU28318. For functional analysis of RU40555 we have examined the ability of RU40555 to antagonize dexamethasone (GR selective agonist) suppression of the HPA axis response to acute stress. The suppression of the corticosterone acute stress response by dexamethasone has been well established as a sensitive GR mediated effect [1].

A limitation of these functional tests is that they may not directly test the antagonist properties of these compounds within the brain. There is evidence for a central site of action for aldosterone modulation of sodium appetite $[29,30]$, although the hippocampus is probably not involved [31]. There is the possibility, however, that the normalization of saline intake by a systemic dose of aldosterone is secondary to normalization of sodium retention within the kidney. In addition, the suppressive effect of dexamethasone on HPA axis activity has been repeatedly demonstrated to depend primarily on dexamethasone activation of GR located in the pituitary [32-34]. Nevertheless, by combining these functional tests with evaluation of the ability of RU28318 and RU40555 to occupy corticosteroid receptors within the brain and pituitary, a better in vivo validation of the selective antagonistic properties of these compounds is provided than has previously been reported.

\section{MATERIALS AND METHODS}

\section{Subjects}

Experimental subjects were male Sprague Dawley rats (285-350 g at time of experimentation) purchased from Harlan Sprague Dawley (Indianapolis, IN). Animals were housed in wire mesh hanging cages ( 3 rats per cage) and were given food (Purina laboratory rat chow) and tap water ad lib. The animal room was maintained on a $12 \mathrm{~h}$ light:dark cycle (lights on at 7.00 a.m.). All experimental procedures were conducted in the a.m. After arrival at the University of Colorado at Boulder animal care facilities the animals were given a 2 week acclimation period before onset of experimentation. All exper- 
iments were approved by the University of Colorado Institutional Animal Care and Use Committee.

\section{Corticosteroid agonists and antagonists}

The MR antagonist used for these studies was RU28318 ([7,17alpha]-17-hydroxy-3oxo-7-proplpregn-xene-21-carboxylic acid potassium). The GR antagonist used for these studies was RU40555 (17beta-hydroxy-11-beta-/4-/[methyl]-[1-methylethyl]aminophenyl/-17alpha-[prop-1-ynyl] estra-4-9-diene-3one). Both antagonists were donated by RousselUclaf (Romainville, France). Aldosterone and dexamethasone were used as selective MR and GR agonists, respectively. Although dexamethasone binds MR with a high affinity in an in vitro receptor binding assay $[16,35]$, in vivo dexamethasone is a selective agonist for GR [36]. Aldosterone and dexamethasone were purchased from Sigma (St. Louis, MO). Propylene glycol was used as the vehicle for all antagonists and agonists. For receptor binding studies $\left[1,2,4-{ }^{3} \mathrm{H}\right]$-dexamethasone (S.A. $=50 \mathrm{Ci} / \mathrm{mmol}$ ) was obtained from Amersham (Arlington Heights, IL). For corticosterone radioimmunoassay [1,2,6,7$\left.{ }^{3} \mathrm{H}(\mathrm{N})\right]$-corticosterone $\quad(\mathrm{S} . \mathrm{A} .=80 \mathrm{Ci} / \mathrm{mmol}$ ) was obtained from New England Nuclear (Boston, MA).

\section{ESTIMATES OF IN VIVO RECEPTOR OCCUPATION BY ANTAGONISTS}

\section{Available corticosteroid receptor binding}

Several important features of the receptor binding assay indicates that the available receptor binding data may provide an estimate of in vivo corticosteroid receptor occupation by RU28318 and RU40555 (see DISCUSSION). For all of the receptor binding measures the rats were adrenalectomized $24 \mathrm{~h}$ prior to the day of experimentation to prevent interference from endogenous corticosterone. On the day of experimentation rats were injected with RU28318 or RU40555 (see below for doses) and were then killed by rapid decapitation 1 or $2 \mathrm{~h}$ later. Immediately following decapitation, the hippocampus and pituitary were rapidly removed and stored at $-70^{\circ} \mathrm{C}$. Trunk blood was also collected for determination of plasma corticosterone. None of the plasma samples from adrenalectomized rats had plasma corticosterone levels above detection limits of our assay $(0.5 \mu \mathrm{g} /$ $100 \mathrm{ml}$, for a $20 \mu \mathrm{l}$ sample).

The available cytosolic MR and GR binding was measured using a radioligand receptor binding assay [16]. Tissues from individual animals were homogenized in a buffer solution comprised of $10 \mathrm{mM}$ Tris, $1 \mathrm{mM}$ EDTA, $10 \%$ glycerin, $20 \mathrm{mM}$ molybdic acid and $5 \mathrm{mM}$ dithiothreitol at a $\mathrm{pH}$ of 7.4 at $4{ }^{\circ} \mathrm{C}$. The homogenate was centrifuged $(100,000 \mathrm{~g}, 30 \mathrm{~min})$ and $150 \mu \mathrm{l}$ of the supernatant fraction (cytosol) was incubated for $18-24 \mathrm{~h}$ in the presence of $200 \mu \mathrm{l}$ of
[3H]-dexamethasone (10 nM, final concentration) \pm non-radioactive competitors. [3H]-Dexamethasone was used because of its high affinity for both $M R$ and $\mathrm{GR}$ in vitro $[16,35]$. Available GR binding was determined from the amount of total $[3 \mathrm{H}]$-dexamethasone binding that was displaced by the selective GR ligand RU28362 (0.5 $\mu \mathrm{M})$ [9]. Available MR binding was determined by the amount of residual [3H]-dexamethasone specific binding. Nonspecific binding was defined as the amount of $[3 \mathrm{H}]$-dexamethasone binding that was not displaced by an excess of dexamethasone $(10 \mu \mathrm{M})$. Non-specific binding was less than $10 \%$ of total binding. Bound $[3 \mathrm{H}]$-dexamethasone was separated from unbound steroid by gel filtration ( $100 \mu \mathrm{l}$ per incubate in triplicate) in $1 \mathrm{ml}$ Sephadex (LH-20, Pharmacia) columns. The resulting eluate was mixed with scintillation cocktail and the radioactivity was measured using a scintillation counter. Protein concentrations for each cytosolic sample were determined using a Bradford assay [37]; bovine serum albumin was used for the protein standard. The final protein levels in each incubation tube ranged from $0.5-1.5 \mathrm{mg} / \mathrm{ml}$.

Experiment 1: dose- and time-response study of the effect of RU28318 on available MR and GR binding in the hippocampus

The in vivo selectivity of a range of doses of RU28318 for MR was tested. For the dose-response comparison adrenalectomized rats $(n=3-4)$ were injected s.c. $1 \mathrm{~h}$ before death with either vehicle (propylene glycol, $1 \mathrm{ml} / \mathrm{kg}$ ) or one of three doses of RU28318 (10, 25 or $50 \mathrm{mg} / \mathrm{kg})$. An additional group of adrenalectomized rats $(n=3)$ was injected with the highest dose of RU28318 (50 mg/kg) and were killed $2 \mathrm{~h}$ after injection. The $2 \mathrm{~h}$ time-point was included in order to provide some indication as to whether the effects of the antagonists would be sustained for at least $2 \mathrm{~h}$ after injection.

Experiment 2: dose- and time-response study of the effect of RU40555 on available $M R$ and GR binding in the hippocampus

Following the same design as experiment 1, the in vivo selectivity of a range of doses of RU40555 for GR was tested. For the dose-response comparison adrenalectomized rats $(n=3-4)$ were injected s.c. $1 \mathrm{~h}$ before death with either vehicle (propylene glycol, $3 \mathrm{ml} / \mathrm{kg}$ ) or one of three doses of RU40555 (10, 20, or $30 \mathrm{mg} / \mathrm{kg}$ ). An additional group of adrenalectomized rats $(n=3)$ was injected with the highest dose of RU40555 (30 mg/kg) and was killed $2 \mathrm{~h}$ after injection. Due to the poor solubility of RU40555, all injection solutions were adjusted to an injection volume of $3 \mathrm{ml} / \mathrm{kg}$. 
Experiment 3: comparison of the effects of RU28318 and $R U 40555$ on available $M R$ and GR binding in the hippocampus and the pituitary

This experiment compared the effect of antagonist treatment on available $\mathrm{MR}$ and GR binding in both the hippocampus and the pituitary $(n=5-6)$. Vehicle (propylene glycol, $3 \mathrm{ml} / \mathrm{kg}$, s.c.), RU28318 (50 mg/kg, s.c.) or RU40555 (30 mg/kg, s.c.) were injected in adrenalectomized rats. Rats were then killed $60 \mathrm{~min}$ later.

\section{FUNCTIONAL STUDIES}

Experiment 4: mineralocorticoid receptor dependent functional bioassay

A functional validation of the ability of RU28318 to antagonize an MR dependent effect in vivo was conducted using the 'two water bottle drinking test' in adrenalectomized rats. This test relies on the voluntary increased saline intake observed in rats after adrenalectomy. Low dose aldosterone replacement is known to reverse the increased saline intake $[28,29]$. Subjects were individually housed and were given the choice of two drinking bottles filled with either tap water or $0.9 \%$ saline. The relative daily liquid intakes were monitored by measuring the weight of the two water bottles over a $24 \mathrm{~h}$ period. The change in weight of the water bottles was then converted into the volume consumed $(1 \mathrm{~g}=1 \mathrm{ml})$. All subjects except for the Sham rats were adrenalectomized 1 week prior to the onset of treatment. The subjects were then injected with antagonist (RU28318, $50 \mathrm{mg}$ / $\mathrm{kg}$, s.c.) or vehicle (propylene glycol, $1 \mathrm{ml} / \mathrm{kg}$ s.c.) and $45 \mathrm{~min}$ later were injected with agonist (aldosterone, $120 \mu \mathrm{g} / \mathrm{kg}$, s.c.) or vehicle (propylene glycol, $1 \mathrm{ml} / \mathrm{kg}$ s.c.). Thus, adrenalectomized rats were given one of the following four treatment combinations: (1) vehicle + vehicle, (2) RU28318 + vehicle, (3) vehicle + aldosterone or (4) RU28318 + aldosterone $(n=3-4)$. Sham rats were given only vehicle injections. Treatments were given to each rat on two consecutive days. 24-h intake was measured each morning. On treatment days the measurement of water intake was followed by injection.

\section{Experiment 5: glucocorticoid receptor dependent functional bioassay}

Dexamethasone is a potent and relatively selective GR agonist in vivo [36] and has been consistently shown to suppress the stress-induced rise in corticosterone [1]. Therefore, we examined the ability of RU40555 to block the effect of dexamethasone on corticosterone secretion during $1 \mathrm{~h}$ of restraint stress. RU40555 (30 mg/kg, s.c.) or vehicle (propylene glycol, $3 \mathrm{ml} / \mathrm{kg}$, s.c.) was injected $90 \mathrm{~min}$ prior to the onset of restraint stress, while dexamethasone $(50 \mu \mathrm{g} /$ $\mathrm{kg}$, s.c.) or vehicle (propylene glycol, $1 \mathrm{ml} / \mathrm{kg}$, s.c.) was injected $60 \mathrm{~min}$ prior to the onset of restraint stress. Thus, there were 4 combinations of drug treatment: (1) vehicle + vehicle, (2) RU40555 + vehicle, (3) vehicle + dexamethasone and (4) RU40555 + dexamethasone $(n=4)$. These manipulations were performed during the first third of the light period. Restraint consisted of placing rats in a Plexiglas tube $(23.5 \mathrm{~cm}$ in length and $7 \mathrm{~cm}$ in diameter) that inhibited forward/backward and lateral movement. Serial blood samples (approximately $100 \mu \mathrm{l} / \mathrm{sample})$ were collected from the tip of the tail of each rat at $0,30,60,90$ and $120 \mathrm{~min}$ after the onset of stress. Plasma corticosterone was measured by radioimmunoassay. Plasma samples were diluted 1:50 in 0.01 M PBS and corticosteroid binding globulins were heat inactivated by incubating the diluted samples for $1 \mathrm{~h}$ at $70^{\circ} \mathrm{C}$. Samples and corticosterone standards (25-2000 pg per tube) were incubated overnight with antiserum (B21-42, Endocrine Sciences, Tarzana, CA) and $[3 \mathrm{H}]$ corticosterone (20,000 cpm/tube). Antibody-bound steroid was separated from free steroid with dextran-coated activated charcoal. The antibody bound steroid was then mixed with scintillation cocktail and the radioactivity was counted using a scintillation counter. Assay sensitivity was $0.5 \mu \mathrm{g} / 100 \mathrm{ml}$ for an assay volume of $20 \mu \mathrm{l}$ of plasma. All samples were analyzed within the same assay. The intra-assay coefficient of variation was $9.5 \%$ for a sample containing approximately $5 \mu \mathrm{g} /$ $100 \mathrm{ml}$ and $4.4 \%$ for a sample containing approximately $20 \mu \mathrm{g} / 100 \mathrm{ml}(n=4)$.

\section{Data analysis and statistics}

Statistical analysis was conducted with aid of the computer statistics package Systat (Evanston, IL). Overall statistical significance of mean differences between three or more groups was determined by analysis of variance. Post hoc tests of difference between two groups was determined by the Tukey's test. For experiment 4 the Student's paired $t$-test was used to determine whether there was a significant difference in saline intake for a particular group of rats before and after treatment. For all statistical tests the significance level was $p=0.05$. Data are presented as the mean \pm SEM.

\section{RESULTS}

Experiment 1: dose- and time-response study of the effect of RU28318 on available $M R$ and GR binding in the hippocampus

Acute treatment with RU28318 produced a doserelated decrease in available $\mathrm{MR}$ binding, $F(4$, $12)=25.6, p<0.01$ [Fig. 1(A)]. The highest dose of RU28318 (50 mg/kg) produced greater than an $85 \%$ decrease in available MR by one hour after injection, which was still present at the $2 \mathrm{~h}$ time point 
$1 \mathrm{~A}$

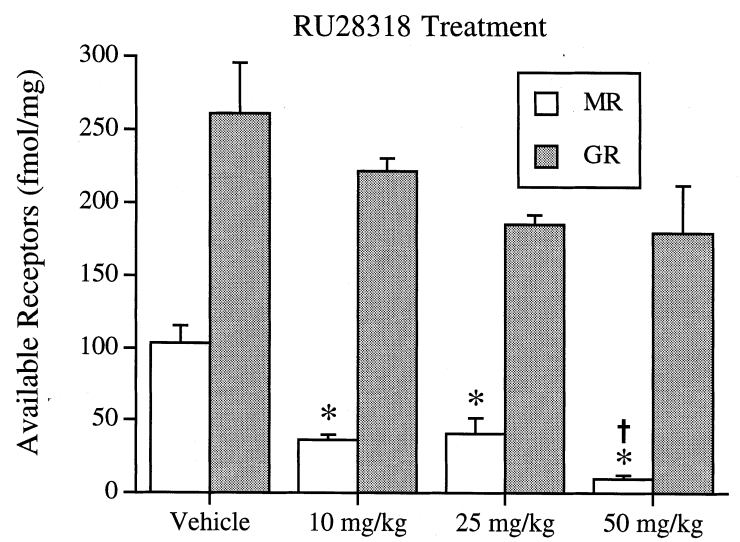

1B

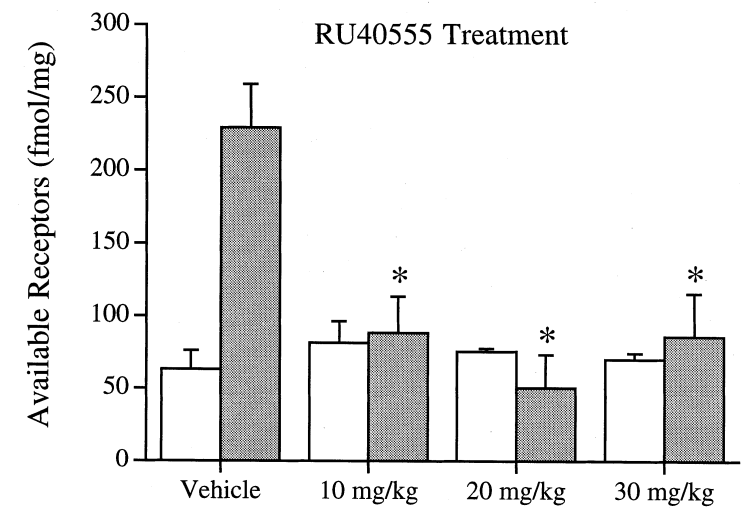

Fig. 1. Dose-response effect of RU28318 or RU40555 on available corticosteroid receptor binding levels in hippocampus. All rats $(n=3-4)$ were adrenalectomized $24 \mathrm{~h}$ before treatment. Rats were injected s.c. with vehicle or drug $1 \mathrm{~h}$ before sacrifice. Panel 1A shows the effect of RU28318 (10, 25 or $50 \mathrm{mg} / \mathrm{kg}$ ) injection on ex-vivo measure of available cytosolic mineralocorticoid receptor (MR) or glucocorticoid receptor (GR) binding. Panel 1B shows the effect of RU40555 (10, 20 or $30 \mathrm{mg} / \mathrm{kg}$ ) injection on the same receptor measures. *Significantly different from vehicle treatment for the same receptor subtype measure, $p<0.05$, Tukey's test. 'Significantly different from 10 and $25 \mathrm{mg} / \mathrm{kg}$ RU28318 treatment groups for the same receptor subtype measure, $p<0.05$, Fisher's least significant difference test.

[Fig. 2(A)]. The level of available MR in the highest dose RU28318 treatment group was significantly lower than the level of available MR in the two lower dose RU28318 treatment groups as determined by the Fisher's least significant difference post hoc test [Fig. 1(A)]. RU28318 appeared to have a small effect on available GR binding, but this effect was not statistically significant.

Experiment 2: dose- and time-response study of the effect of RU40555 on available $M R$ and GR binding in the hippocampus

All three doses of RU40555 produced a $70-80 \%$ decrease in available GR binding, $F(4,11)=9.2$, $p<0.01$ [Fig. 1(B)]. The decrease in available GR binding was comparable at both the 1 and $2 \mathrm{~h}$ time
RU28318 Treatment

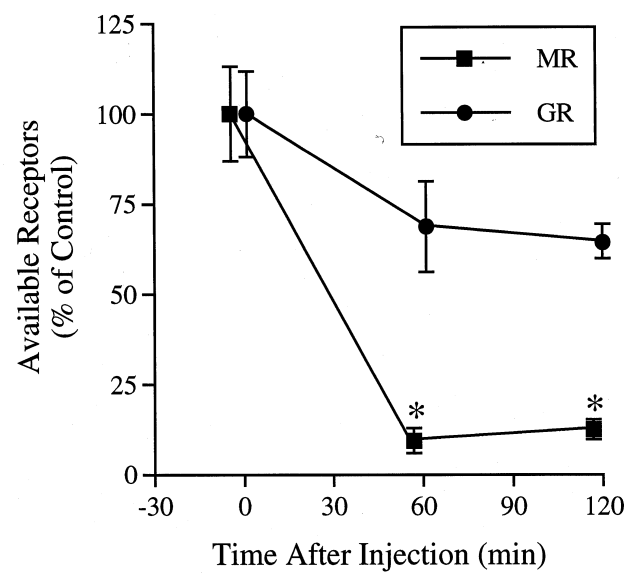

2B

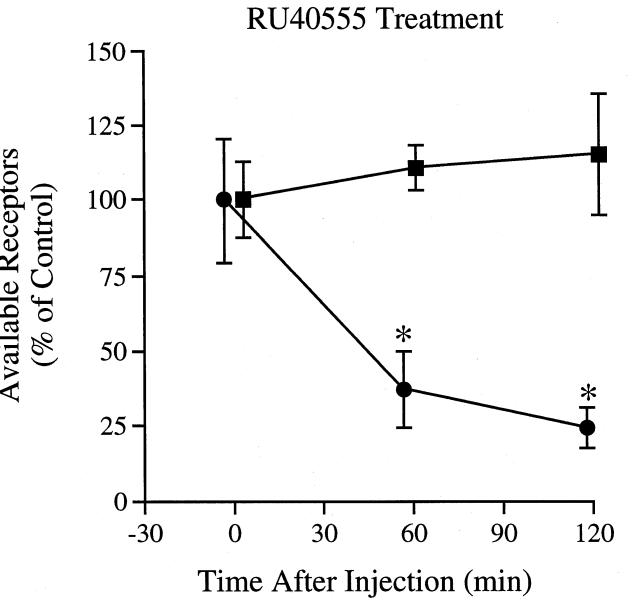

Fig. 2. Time-response effect of RU28318 or RU40555 on available corticosteroid receptor binding levels in hippocampus. All rats $(n=3-4)$ were adrenalectomized $24 \mathrm{~h}$ before treatment. Rats were injected s.c. with vehicle (time 0 ) or drug. The drug treated rats were sacrificed 60 or $120 \mathrm{~min}$ after injection. Data are expressed as the mean percent of the mean value for the vehicle (control group). The raw data for the vehicle and $60 \mathrm{~min}$ post drug groups are presented in Fig. 1. Panel 2A shows the effect of RU28318 (50 mg/kg) injection on ex-vivo measure of available cytosolic mineralocorticoid receptor (MR) or glucocorticoid receptor (GR) binding. Panel 2B shows the effect of RU40555 (30 mg/kg) injection on the same receptor measures. ${ }^{*}$ Significantly different from vehicle treatment (time 0 ) for the same receptor subtype measure, $p<0.05$, Tukey's test.

points [Fig. 2(B)]. RU40555 treatment produced no significant effect on available $M R$.

Experiment 3: comparison of the effects of RU28318 and RU40555 on available $M R$ and GR binding in the hippocampus and the pituitary

This experiment was conducted in order to determine whether the acute effects of RU28318 and RU40555 on available hippocampal corticosteroid receptor binding observed in experiments 1 and 2 would be extended to the pituitary. In addition, since there was some suggestion in experiment 1 that 
$3 \mathrm{~A}$

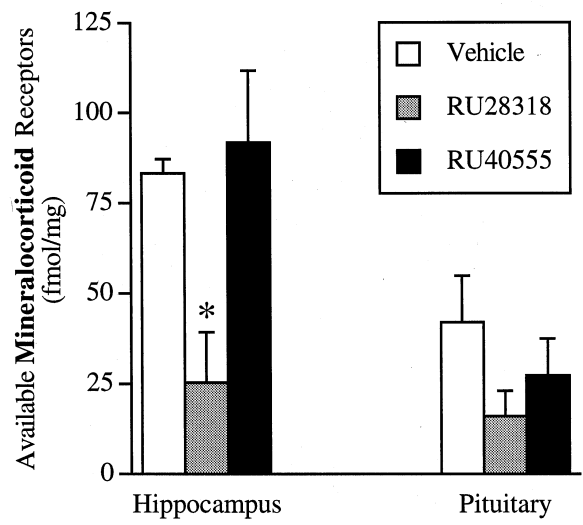

3B

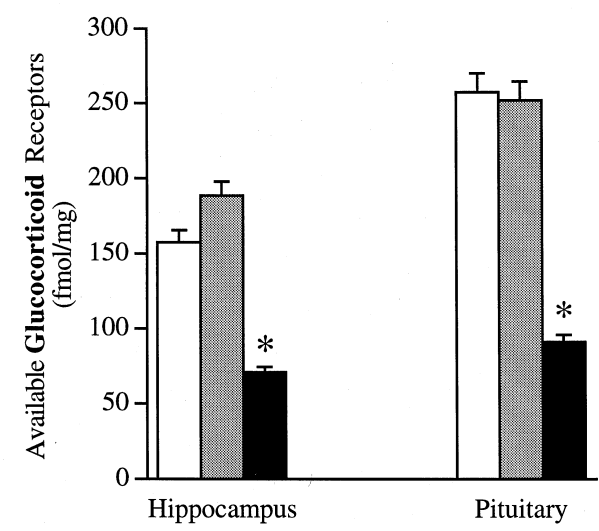

Fig. 3. Effect of RU28318 or RU40555 on available corticosteroid receptor binding levels in hippocampus and pituitary. All rats $(n=5-6)$ were adrenalectomized $24 \mathrm{~h}$ before treatment. Rats were injected s.c. with vehicle or drug $1 \mathrm{~h}$ before sacrifice. Panel 3A shows the effect of RU28318 $(50 \mathrm{mg} / \mathrm{kg})$ or RU40555 (30 mg/kg) injection on ex-vivo measure of available cytosolic mineralocorticoid receptor (MR) binding. Panel 3B shows the effect of RU28318 (50 mg/kg) or RU40555 (30 mg/ $\mathrm{kg}$ ) injection on ex-vivo measure of available cytosolic glucocorticoid receptor (GR) binding. *Significantly different from vehicle treatment, $p<0.05$, Tukey's test.

RU28318 had a small effect on available GR binding in the hippocampus, hippocampal tissue was re-examined in this experiment. The highest dose of both compounds tested in experiments 1 and 2 were used for this experiment since the previous experiments indicated that they were as selective for $M R$ or $G R$ as were the lower doses and, in the case of RU28318, the highest dose produced a greater effect on available receptors than was produced by the two lower doses.

RU28318 produced a statistically significant $70 \%$ decrease in available MR binding in the hippocampus [Fig. 3(A)]. RU28318 produced a similar magnitude of decrease in available MR binding in the pituitary, however, partly due to the relatively low MR expression in the pituitary, even in the vehicle treated group, this effect was not statistically significant [Fig. 3(A)]. In this experiment which contained larger sample sizes than experiment 1 , there was no trend

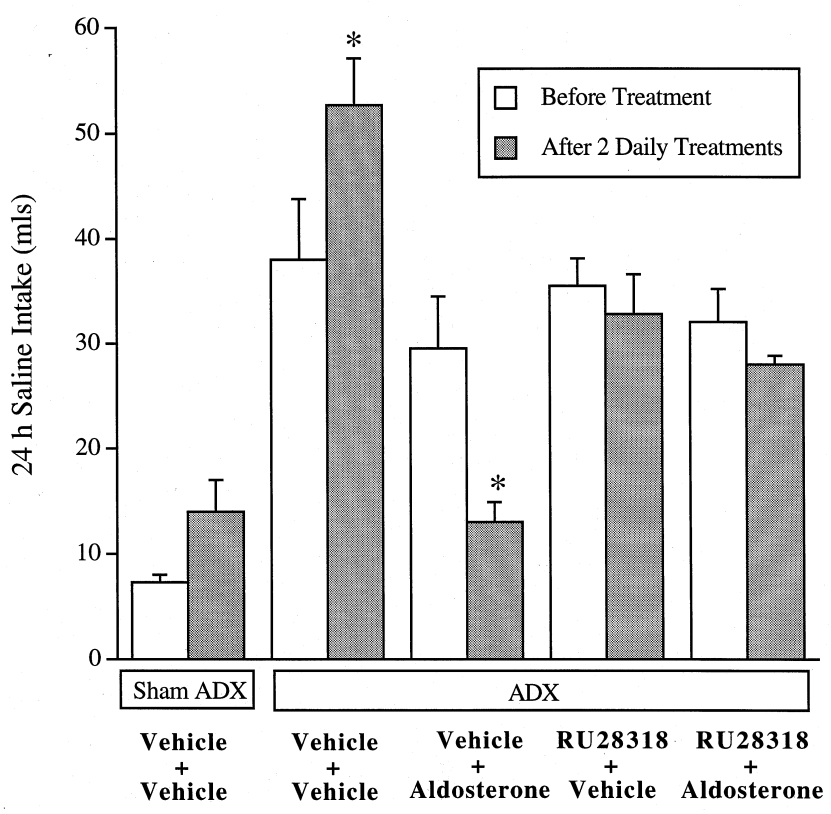

Fig. 4. RU28318 blockade of the normalizing effect of aldosterone on saline intake of adrenalectomized rats. Rats were adrenalectomized (ADX) or sham adrenalectomized 1 week before the beginning of the experiment. Rats were individually housed and each rat was given access to two water bottles, one containing tap water and another containing $0.9 \%$ saline. $24 \mathrm{~h}$ intake was monitored both before treatment and after two consecutive days of treatment. Daily treatment consisted of injection with vehicle or RU28318 (50 mg/kg, s.c.) followed $45 \mathrm{~min}$ later by injection with vehicle or aldosterone $(120 \mu \mathrm{g} / \mathrm{kg}$, s.c.). *Significantly different from the pre-treatment intake for the same treatment group, $p<0.05$, Student's dependent $t$-test $(n=3-4)$.

for an effect of RU28318 treatment on available GR binding in either the hippocampus or the pituitary.

RU40555 produced a significant $65 \%$ decrease in available GR binding in both the hippocampus and the pituitary [Fig. 3(B)]. RU40555 had no significant effect on $M R$ binding in either tissue.

Experiment 4: mineralocorticoid receptor dependent functional bioassay

1 week following adrenalectomy there was a substantially greater amount of saline intake in adrenalectomized rats $(33 \pm 2 \mathrm{ml} /$ day $)$ compared to sham adrenalectomized rats $(7 \pm 1 \mathrm{ml} /$ day) (Fig. 4$)$. There was also a reciprocal decrease in tap water intake of adrenalectomized rats $(15 \pm 2 \mathrm{ml} /$ day $)$ compared to sham adrenalectomized rats $(28 \pm 3 \mathrm{ml} /$ day) (data not shown). Upon treatment with aldosterone, adrenalectomized rats significantly decreased their saline intake to levels that were comparable to sham adrenalectomized rats (Fig. 4). Treatment of adrenalectomized rats with RU28318 or RU28318 + aldosterone did not produce a decrease in saline intake. The adrenalectomized rats given vehicle treatment exhibited a small but significant increase in saline intake. 


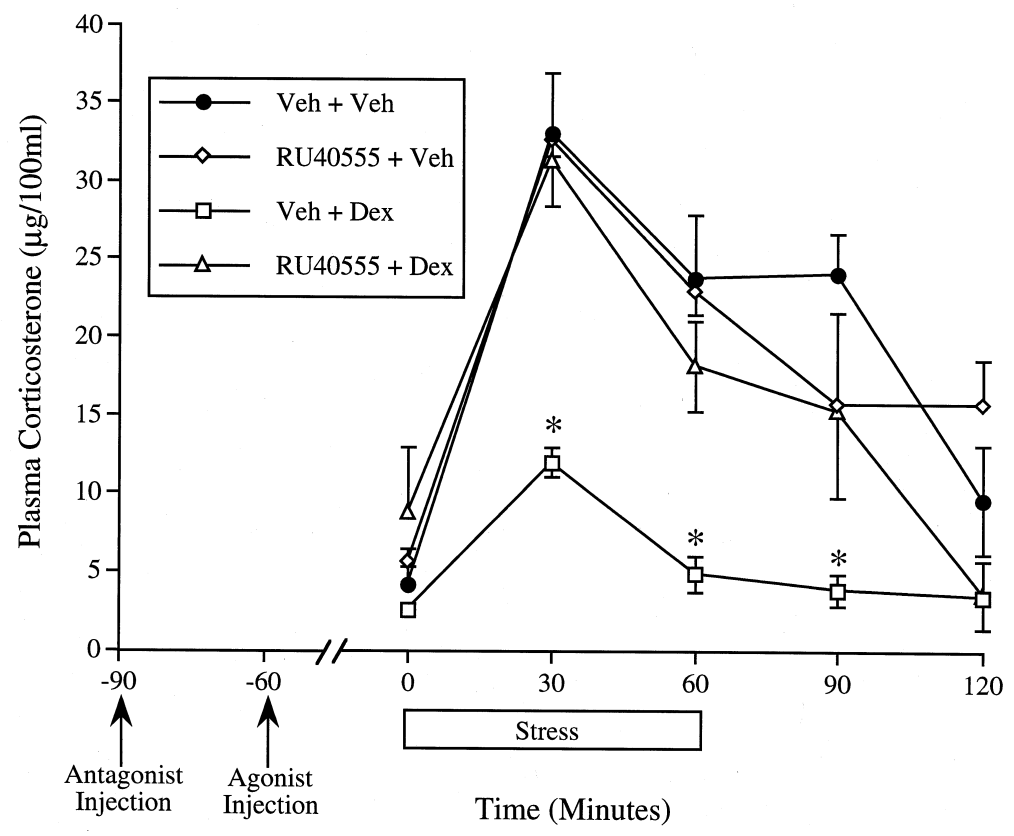

Fig. 5. RU40555 blockade of the suppressive effect of dexamethasone on stress-induced corticosterone secretion. Rats were exposed to $60 \mathrm{~min}$ of stress (restraint). Blood samples for plasma corticosterone measurement were taken from the tip of the tail at the time points indicated. Rats were injected 90 min prior to restraint with either vehicle (Veh) or RU40555 $(30 \mathrm{mg} / \mathrm{kg}$, s.c.) and were injected again 60 min prior to restraint with either vehicle or dexamethasone $(50 \mu \mathrm{g} / \mathrm{kg}, \mathrm{s.c}$.$) . { }^{\star}$ Significantly different from the vehicle + vehicle treated rats at the same time point, $p<0.05$, Tukey's test $(n=4)$.

Experiment 5: glucocorticoid receptor dependent functional bioassay

Treatment with dexamethasone (50 $\mu \mathrm{g} / \mathrm{kg}$ s.c.) produced a substantial decrease in plasma corticosterone levels both during and after one hr of restraint stress (Fig. 5). RU40555 (30 mg/kg s.c.) pretreatment completely blocked the effect of dexamethasone. RU40555 treatment alone had no effect on plasma corticosterone levels throughout the experiment.

\section{DISCUSSION}

Acute treatment of adrenalectomized rats with RU28318 or RU40555 produced a selective decrease in MR and GR cytosolic binding, respectively. These observed decreases in receptor binding may reflect the in vivo corticosteroid receptor occupation by RU28318 and RU40555. Several studies have demonstrated that only the unactivated form of corticosteroid receptors are available for radioligand binding in a cytosolic binding assay $[16,38,39]$. This may be largely a result of the absence of the activated receptor in the cytosolic tissue fraction due to nuclear translocation [40]. In addition, the activated form of the receptor does not participate in an in vitro exchange assay $[16,38,39]$. Consequently, only corticosteroid receptors that are unoccupied and unactivated by endogenous or exogenous steroid at the time of sacrifice can be measured in the cytosolic receptor binding assay. Interestingly, several studies have indicated that not only GR agonists, but also the GR an- tagonists, RU486 and RU40555, cause activation and nuclear translocation of GR [41-44]. Thus, GR antagonism appears to be dependent on processes subsequent to receptor activation and nuclear translocation, such as decreased stability of the activated receptor state and impaired ability of the activated receptor to modulate gene transcription. Similar mechanistic studies of MR antagonists have been less extensive, perhaps largely due to the limited availability of MR reactive antibodies. A recent study utilizing an insect cell line transfected with human MR found that several different $M R$ antagonists appeared to produce translocation of MRs, however, the translocation was poorly sustained relative to that seen by the agonist, aldosterone [45]. Our results indicate that RU28318 and RU40555 interact with MR and GR in vivo in such a way that makes these receptors unavailable for subsequent ex-vivo radioligand binding. Since in our studies rats were killed within $1-2 \mathrm{~h}$ after treatment with the antagonists, the observed decrease in available receptor binding is most likely a result of antagonist-induced alteration of the state of the receptor, such as receptor activation and nuclear translocation, rather than a rapid change in receptor expression [46]. These results suggest that under our experimental conditions both compounds produced activation/translocation of a substantial proportion of MR or GR.

The selectivity of in vivo treatment with RU28318 on available MR seen in our studies is important to note given that in vitro this compound has been 
reported to have a relatively low selectivity for binding of MR over GR $[8,9]$. This discrepancy may be explained by the finding that RU28318 in vivo is rapidly converted into its gamma-lactone form (RU26752; Roussel-Uclaf, internal report) which is highly selective for MR in vitro $[8,9]$.

After determining a dose of RU28318 and RU40555 that resulted in both high occupancy and selectivity for $M R$ and GR, respectively, we examined the ability of each compound to antagonize a physiological effect produced by a selective MR or GR agonist. We used aldosterone regulation of sodium intake as a bioassay to study the in vivo effectiveness of RU28318 as a MR antagonist. As previously reported $[28,29]$, we found that rats significantly increased their preference for saline containing water over tap water after adrenalectomy, and that this effect was reversed by aldosterone treatment. RU28318 treatment was able to block the normalizing effect of aldosterone on saline intake. Thus, this result supports the functional capability of a MR selective dose of RU28318 to antagonize an MR mediated effect. RU28318 appeared to have very little effect of its own on saline intake in adrenalectomized rats. It should be noted, however, that vehicle treated adrenalectomized rats had progressively greater saline intake over the two day treatment period, whereas the saline intake of RU28318 rats did not increase after treatment. This may merely reflect between group variability in saline intake, however, it may reflect a low level inhibition of saline intake by RU28318 (a partial agonist effect).

In order to study the in vivo effectiveness of RU40555 to antagonize a GR mediated effect, we examined dexamethasone suppression of stressinduced corticosterone secretion. We have found in a dose-response study that dexamethasone $(50 \mu \mathrm{g} / \mathrm{kg}$ s.c.) produces a near maximal suppression of corticosterone secretion during restraint stress (unpublished observations). As noted in Section 1, the pituitary appears to be the primary site of action for this inhibitory effect of dexamethasone [32-34]. RU40555 was able to completely block this effect of dexamethasone. RU40555 by itself had no effect on stress-induced corticosterone secretion. The lack of a suppressive effect of RU40555 on corticosterone secretion is noteworthy given that the more widely used GR antagonist RU486 has been reported to partially suppress stress-induced corticosterone responses in rats [13] and to partially suppress CRH stimulated ACTH secretion in humans [12]. These effects of RU486 are probably evidence for a partial agonist effect of this compound on HPA axis activity. An accumulating number of papers have reported glucocorticoid agonist-like effects of RU486 [10-14]. Thus, RU40555 may prove to be an effective alternative to RU486 for blocking glucocorticoid effects in situations where RU486 alone has demonstrated agon- istic properties. On the other hand, a limitation of RU40555 appears to be its low solubility in the face of its relatively low antagonistic potency. Based on our studies of the effects of RU40555 treatment on available receptors, even the highest dose tested $(30 \mathrm{mg} / \mathrm{kg})$ produced only a $65-80 \%$ decrease in available receptors. This result suggests that our treatment with RU40555 did not produce complete blockade of GR. However, there is the possibility that some of the antagonistic effects of RU40555 on GR are produced by competition with agonist for the binding site without production of receptor activation and nuclear translocation. Thus, the effect of RU40555 treatment on available GR binding may underestimate the proportion of GR antagonism produced by RU40555. Regardless of whether our RU40555 treatment produced total GR blockade, it was sufficient to completely block the corticosterone suppressing effect of dexamethasone.

The evidence in this study for systemic doses of RU28318 and RU40555 to selectively occupy MR and GR in the hippocampal formation is important given the growing number of studies that have found effects of putative MR and GR selective antagonists on hippocampal related function. For example, RU28318, spironolactone and RU486 have all been shown to modify performance in a Morris water maze task [47-49]. RU486 and RU40555 treatment have also been found to affect contextual fear conditioning [50], whereas RU28318 treatment blocked corticosteroid modulation of reactivity to spatial novelty [51]. Both contextual fear conditioning and reactivity to spatial novelty are behavioral responses that are dependent on hippocampal processes $[50,51]$. Direct injection of corticosteroid receptor antagonists into the hippocampal formation have also been shown to affect behavior. Bilateral intrahippocampal infusion of spironolactone produced a rapid anxiolytic effect in rats [52], and bilateral infusion of RU486 into the dentate gyrus interfered with the retention of an immobility response in the Porsolt swimming test [53]. Thus, there appears to be separate roles of hippocampal MR and GR in mediating behavioral effects of corticosterone, and the use of selective MR and GR antagonists will undoubtedly continue to be instrumental in further characterizing these roles.

In summary, we found that in vivo treatment with RU28318 or RU40555 produced a selective decrease in available MR or GR, respectively, in hippocampal tissue. A similar effect was seen in pituitary with the caveat that the low level of MR expression in that tissue may have limited the extent to which we were able to detect changes in available MR binding. We also found that RU28318 treatment was effective in blocking an MR-dependent effect of aldosterone, and that RU40555 treatment was effective in blocking a GR-dependent effect of dexamethasone. These data 
support the validity of using these two compounds for in vivo studies designed to determine the relative role of MR and GR in mediating the effects of corticosterone.

Acknowledgements-This work was supported by NIH grants MH54742 and DK49143 and by the University of Colorado Undergraduate Research Opportunity Program.

\section{REFERENCES}

1. Dallman M. F., Akana S. F., Cascio C. S., Darlington D. N., Jacobson L. and Levin N., Regulation of ACTH secretion: variations on a theme of B. 1987 Recent Prog. Horm. Res. 43 (1987) 113-173.

2. Herman J. P. and Cullinan W. E., Neurocircuitry of stress: central control of the hypothalamo-pituitary-adrenocortical axis. Trends Neurosci. 20 (1997) 78-84.

3. Arriza J. L., Weinberger C., Cerelli G., Glaser T. M., Handelin B. L., Housman D. E. and Evans R. M., Cloning of human mineralocorticoid receptor complementary DNA: structural and functional kinship with the glucocorticoid receptor. Science 237 (1987) 268-275.

4. Hollenberg S. M., Weinberger C., Ong E. S., Cerelli G., Oro A., Lebo R., Thompson E. B., Rosenfeld M. G. and Evans R. M., Primary structure and expression of a functional human glucocorticoid receptor cDNA. Nature 318 (1985) 635-641.

5. Reul J. M. H. M. and de Kloet E. R., Two receptor systems for corticosterone in rat brain: microdistribution and differential occupation. Endocrinology 117 (1985) 2505-2511.

6. de Kloet E. R., Oitzl M. S. and Joels M., Functional implications of brain corticosteroid receptor diversity. Cell. Mol. Neurobiol. 4 (1993) 433-455.

7. Perroteau I., Netchitailo P., Delarue C., Leboulenger F., Philibert D., Deraedt R. and Hubert V., The effect of the antimineralocorticoid RU28318 on aldosterone biosynthesis in vitro. F. Steroid Biochem. 20 (1984) 853-856.

8. Sutanto W. and de Kloet E. R., ZK91587: a novel synthetic antimineralocorticoid displays high affinity for corticosterone (type I) receptors in the rat hippocampus. Life Sci. 43 (1988) $1537-1543$.

9. Coirini H., Magarinos A. M., De Nicola A. F., Rainbow T. C. and McEwen B. S., Further studies of brain aldosterone binding sites employing new mineralocorticoid and glucocorticoid receptor markers in vitro. Brain Res. 361 (1985) 212-216.

10. Bradbury M. J., Akana S. F., Cascio C. S., Levin N., Jacobson L. and Dallman M. F., Regulation of basal ACTH secretion by corticosterone is mediated by both type I (MR) and type II (GR) receptors in rat brain. F. Steroid Biochem. Molec. Biol. 40 (1991) 133-142.

11. Gruol D. J. and Altschmied J., Synergistic induction of apoptosis with glucocorticoids and $3^{\prime}, 5^{\prime}$-cyclic adenosine monophosphate reveals agonist activity by RU486. Mol. Endocrinol. 7 (1993) 104-113.

12. Laue L., Chrousos G. P., Loriaux D. L., Barnes K., Munson P., Nieman L. and Schaison G., The antiglucocorticoid and antiprogestin steroid RU486 suppresses the adrenocorticotropin response to ovine corticotropin releasing hormone in man. F. Clin. Endocrinol. Metab. 66 (1988) 290-293.

13. Ratka A., Sutanto W., Bloemers M. and de Kloet E. R., On the role of brain mineralocorticoid (type I) and glucocorticoid (type II) receptors in neuroendocrine regulation. Neuroendocrinology 50 (1989) 117-123.

14. Whelan C. J., Hughes S. C. and Wren G. P. A., Inhibition of some aspects of acute inflammation of guinea-pig lung by intraperitoneal dexamethasone and mifepristone: demonstration of agonist activity of mifepristone in the guinea-pig. Inflamm. Res. 44 (1995) 131-138.

15. Spencer R. L., Miller A. H., Moday H., Stein M. and McEwen B. S., Diurnal differences in basal and acute stress levels of type I and type II adrenal steroid receptor activation in neural and immune tissues. Endocrinology 133 (1993) 19411950 .
16. Spencer R. L., Young E. A., Choo P. H. and McEwen B. S., Adrenal steroid type I and type II receptor binding: estimates of in vivo receptor number, occupancy and activation with varying level of steroid. Brain Res. 514 (1990) 37-48.

17. Joels M. and De Kloet E. R., Control of neuronal excitability by corticosteroid hormones. Trends Neurosci. 15 (1992) 25-30.

18. Pavlides C., Watanabe Y., Magarinos A. M. and McEwen B. S., Opposing roles of Type I and Type II adrenal steroid receptors in hippocampal long-term potentiation. Neuroscience 68 (1995) 387-394.

19. Diamond D. M., Bennett M. C., Fleshner M. and Rose G. M., Inverted-U relationship between the level of peripheral corticosterone and the magnitude of hippocampal primed burst potentiation. Hippocampus 2 (1992) 421-430.

20. Kuroda U., Watanabe Y., Albeck D. S., Hastings N. B. and McEwen B. S., Effects of adrenalectomy and type I or type II glucocorticoid receptor activation on 5-HT1A and 5-HT2 receptor binding and 5-HT transporter mRNA expression in rat brain. Brain Res. 648 (1994) 157-161.

21. Meijer O. C., Cole T. J., Schmid W., Schutz G., Joels M. and de Kloet E. R., Regulation of hippocampal 5-HT1A receptor mRNA and binding in transgenic mice with a targeted disruption of the glucocorticoid receptor. Brain Res. Mol. Brain Res. 46 (1997) 290-296.

22. Mendelson S. C. and McEwen B. S., Autoradiographic analyses of the effects of adrenalectomy and corticosterone on 5HT1A and 5-HT1B receptors in the dorsal hippocampus and cortex of the rat. Neuroendo. 55 (1992) 444-450.

23. Watanabe Y., Weiland N. G. and McEwen B. S., Effects of adrenal steroid manipulations and repeated restraint stress on dynorphin mRNA levels and excitatory amino acid receptor binding in hippocampus. Brain Res. 680 (1995) 217-225.

24. Woolley C. S., Gould E. and McEwen B. S., Exposure to excess glucocorticoids alters dendritic morphology of adult hippocampal pyramidal neurons. Brain Res. 531 (1990) 225-231.

25. Gould E., Woolley C. S., Cameron H. A., Daniels D. C. and McEwen B. S., Adrenal steroids regulate postnatal development of the rat dentate gyrus. II. Effects of glucocorticoids and mineralocorticoids on cell birth. F. Comp. Neurol. 313 (1991) 486-493.

26. Woolley C. S., Gould E., Sakai R. R., Spencer R. L. and McEwen B. S., Effects of aldosterone or RU28362 treatment on adrenalectomy-induced cell death in the dentate gyrus of the adult rat. Brain Res. 554 (1991) 312-315.

27. Fregly M. J. and Rowland N. E., Role of renin-angiotensin-aldosterone system in $\mathrm{NaCl}$ appetite of rats. Am. F. Physiol. 248 (1985) R1-R11.

28. Fregly M. J. and Waters I. W., Effect of mineralocorticoids on spontaneous sodium chloride appetite of adrenalectomized rats. Physiol. Behav. 1 (1966) 65-74.

29. McEwen B. S., Lambdin L. T., Rainbow T. C. and de Nicola A. F., Aldosterone effects on salt appetite in adrenalectomized rats. Neuroendo. 43 (1986) 38-43.

30. Sakai R. R., Nicolaidis S. and Epstein A. N., Salt appetite is suppressed by interference with angiotensin II and aldosterone. Am. F. Physiol. 251 (1986) R762-R768.

31. Magarinos A. M., Coirini H., de Nicola A. F. and McEwen B. S., Mineralocorticoid regulation of salt intake is preserved in hippocampectomized rats. Neuroendo. 44 (1986) 494-497.

32. de Kloet E. R., van der Vies J. and de Wied D., The site of suppressive action of dexamethasone on pituitary-adrenal activity. Endocrinology 94 (1974) 61-73.

33. Meijer O. C., de Lange E. C. M., Breimer D. D., de Boer A. G., Workel J. O. and de Kloet E. R., Penetration of dexamethasone into brain glucocorticoid targets is enhanced in mdr1A P-glycoprotein knockout mice. Endocrinology 139 (1998) 1789-1793.

34. Miller A. H., Spencer R. L., Pulera M., Kang S., McEwen B. S. and Stein M., Adrenal steroid receptor activation in rat brain and pituitary following dexamethasone: implications for the dexamethasone suppression test. Biol. Psychiatry 32 (1992) $850-869$.

35. Luttge W. G., Davda M. M., Rupp M. E. and Kang C. G., High affinity binding and regulatory actions of dexamethasonetype I receptor complexes in mouse brain. Endocrinology 125 (1989) 1194-1203. 
36. Schimmer, B. P and Parker, K. L., Adrenocorticotropic hormone; adrenocortical steroids and their synthetic analogs; inhibitors of the synthesis and actions of adrenocortical hormones. In The Pharmacological Basis of Therapeutics, 9th edn, eds J. G. Hardman and L. E. Limbird. McGraw-Hill, New York, 1996, p. 1466, pp. 1459-1485.

37. Bradford M. M., A rapid and sensitive method for the quantitation of microgram quantities of protein utilizing the principle of protein-dye binding. Anal. Biochem. 27 (1976) 248-254.

38. Chou Y. C. and Luttge W. G., Activated type II receptors in brain cannot rebind glucocorticoids: relationship to progesterone's antiglucocorticoid actions. Brain Res. 440 (1988) 67-68.

39. Litwack G., The glucocorticoid receptor at the protein level. Cancer Res. 48 (1988) 2636-2640.

40. O'Donnell D., Francis D., Weaver S. and Meaney M. J., Effects of adrenalectomy and corticosterone placement on glucocorticoid receptor levels in rat brain tissue: a comparison between western blotting and receptor binding assays. Brain Res. 687 (1995) 133-142.

41. Beck C. A., Estes P. A., Bona B. J., Muro-Cacho C. A., Nordeen S. K. and Edwards D. P., The steroid antagonist RU486 exerts different effects on the glucocorticoid and progesterone receptors. Endocrinology 133 (1993) 728-740.

42. Meyer A. S. and Schmidt T. J., Differential effects of agonists and antagonists on autoregulation of glucocorticoid receptors in a rat colonic adenocarcinoma cell line. F. Steroid Biochem. Molec. Biol. 62 (1997) 97-105.

43. Pearce, B. D., Pariante, C. M., Pisell, T. L. and Miller, A. H., Mechanism of action of the glucocorticoid receptor antagonist, RU40555. Program of the 26th Annual Meeting of the Society for Neuroscience. Washington D.C., 1996, p. 2013 (Abstract).

44. van Eekelen J. A. M., Kiss J. Z., Westphal H. M. and de Kloet E. R., Immunocytochemical study on the intracellular localization of the type 2 glucocorticoid receptor in the rat brain. Brain Res. 436 (1987) 120-128.
45. Lombes M., Binart N., Delahaye F., Baulieu E. E. and Rafestin-Oblin M.-E., Differential intracellular localization of human mineralocorticosteroid receptor on binding of agonists and antagonists. Biochem. F. 302 (1994) 191-197.

46. Reul J. M. H. M., van den Bosch F. R. and de Kloet E. R., Relative occupation of type-I and type-II corticosteroid receptors in rat brain following stress and dexamethasone treatment: functional implications. F. Endocrinol. 115 (1987) 459-467.

47. Oitzl M.S . and de Kloet E. R., Selective corticosteroid antagonists modulate specific aspects of spatial orientation learning. Behav. Neurosci. 106 (1992) 62-71.

48. Roozendaal B. and McGaugh J. L., Basolateral amygdala lesions block the memory-enhancing effect of glucocorticoid administration in the dorsal hippocampus of rats. Eur. 7. Neurosci. 9 (1997) 76-83.

49. Smythe J. W., Murphy D., Timothy C., Gul G. H. H. and Costall B., Cognitive dysfunctions induced by scopolamine are reduced by systemic or intrahippocampal mineralocorticoid receptor blockade. Pharmacol. Biochem. Behav. 56 (1997) 613621.

50. Pugh C. R., Fleshner M. and Rudy J. W., Type II glucocorticoid receptor antagonists impair contextual but not auditorycue fear conditioning in juvenile rats. Neurobiol. Learning Mem. 67 (1997) 75-79.

51. Oitzl M. S., Fluttert M. and de Kloet E. R., The effect of corticosterone on reactivity to spatial novelty is mediated by central mineralocorticosteroid receptors. Eur. f. Neurosci. 6 (1994) 1072-1079.

52. Smythe J. W., Murphy D., Timothy C. and Costall B., Hippocampal mineralocorticoid, but not glucocorticoid, receptors modulate anxiety-like behavior in rats. Pharmacol. Biochem. Behav. 56 (1997) 507-513.

53. de Kloet E. R., de Kock S., Schild V. and Veldhuis H. D., Antiglucocorticoid RU 38486 attenuates retention of a behavior and disinhibits the hypothalamic-pituitary adrenal axis at different brain sites. Neuroendocrinology 47 (1988) 109-115. 